\title{
A JÖVŐ TANÁRAINAK IKT ISMERETEI ÉS ELVÁRÁSAI ${ }^{1}$
}

\author{
R. Tóth KRISZTINA ${ }^{*}$ - MOLNÁR GYÖNGYVÉR ${ }^{* *}$ \\ * a Szegedi Tudományegyetem Neveléstudományi Doktori Iskolájának és \\ az MTA-SZTE Képességkutató Csoportjának doktorandusz hallgatója \\ tothkr@edpsy.u-szeged.hu \\ ** a Szegedi Tudományegyetem Neveléstudományi Intézetének és \\ az MTA-SZTE Képességkutató Csoportjának egyetemi docense \\ gymolnar@edpsy.u-szeged.hu
}

\begin{abstract}
Az iskola fó feladata a 21. század tudás társadalmában sem változik, továbbra is az adott kornak megfelelö, releváns tudás közvetitöjének kell lennie. A technológia fejlödése, a mindennapi életben, munkában betöltött szerepének változása, illetve az ezzel kapcsolatos újonnan megfogalmazódó elvárások miatt az oktatásban sem nélkülözhető többé a különbözö IKT (információs-kommunikációs technológia) eszközök használata, illetve hatékony használatuk tanitása. Ez a változás új igényt támaszt a tanárok, illetve a tanárképzés felé. A kutatás célja a tanárképzés kezdetén járó hallgatók $(N=203)$ különböző multimédiás eszközök, web 1.0 és web 2.0-es alkalmazások használatában való jártasságának, illetve a tanárképzés során IKT-val kapcsolatos elvárásainak feltérképezése. Noha a hallgatók többsége a Net Generáció tagja, tanáraik ezt figyelmen kívül hagyva az oktatás folyamán mellözik a web 2.0-es alkalmazásokat. Az eredmények alátámasztják, hogy a tanórai tapasztalat nagymértékben befolyásolja a jövő tanárainak IKT attitüdjét, terveit és gyakorlatát. Azon hallgatók jelentös része nem tartja fontosnak többek között a blogok, wikik vagy a digitális napló használatának elsajátítását, akik korábbi tanulmányaik során nem találkoztak ezekkel az eszközökkel. Ezért a tanárképzés kiemelt feladata, hogy megtanitsa a jövö tanárainak a legújabb IKT eszközök és webes alkalmazások oktatási használatát, ami elösegitené a jövö Net Generációi számára egy hatékonyabb tanitási-tanulási folyamat kialakulását.
\end{abstract}

Az információs és kommunikációs technológiák (IKT) jelentős változást idéztek elö a 21. század társadalmában. Számos területen gyökeresen megváltoztatták az emberek életét, megváltoztatták az emberek közti kommunikációt, a munka természetét és az elvárt tudás fajtáját (UNESCO, 2002). Ennek következtében új ismeretek, készségek és képességek iránti igények jelentek meg a munkaerőpiacon, amit nem hagyhat figyelmen kívül az iskolai oktatás sem.

\footnotetext{
${ }^{1}$ Köszönjük Józsa Krisztiánnak és Tóth Editnek, hogy lehetőséget biztosítottak a kérdőív felvételére. A tanulmány a TAMOP 3.1.9/08/01 kutatási program, az Oktatáselméleti Kutatócsoport és az MTASZTE Képességkutató Csoport keretében készült. A tanulmány írása idején Molnár Gyöngyvér Bolyai János Kutatási Ösztöndíjban részesült.
} 


\section{A Net Generáció és az oktatás jövője}

Számos elképzelés létezik az oktatás jövőjéről. A technokrata elméleteknek számító megközelítések között a legszélsőségesebbek azok, amelyek az oktatás jövőjét a távoktatásban (distance learning), a technológia által közvetített oktatásban (technology mediated education) látják, ahol nincs szükség többé tanárokra (Molnár, 2008). A Microsoft víziója szerint (Hinrichs, 2000) a tanulás 2020-ban technológia alapú és személytelenebb lesz, mint az az ezredfordulón volt. A gyermekeknek megfelelő tudással kell majd rendelkezniük, hogy hatékonyan kiaknázhassák a technológia és az új típusú kommunikációs eszközökben rejlő lehetőségeket. A tanulás egyrészről személyre szabottan, virtuális mentor segítségével történik, másrészröl közösségi alapon, együttmüködést igénylő koordinált projektek által. A video konferenciák minden eszköz repertoárján megjelennek, a digitális kamerák vizuális tartalmakat örökítenek meg, a munkakörnyezetek (workspaces) egyre komplexebbé válnak, és a kooperációs eszközök közvetlen összeköttetésben állnak a digitális könyvtárakkal, amelyek egy életen át végigkísérik a tanulót. A projektorok, számítógépek és az interaktív tábla elterjedésével mára már elkezdődött a mindennapi oktatási tevékenységek jelentős részének technológia alapú környezetre adaptálása, ezáltal érdekesebbé, követhetőbbé téve a tananyagot, fokozva a tanulók tanulási kedvét, melyek megvalósításához nélkülözhetetlenek a jól képzett, IKT-ban jártas pedagógusok.

A 21. század elején már senki sem kételkedik a technológia, az Internet oktatásban betöltött szerepének fontosságában (Hinrichs, 2000). Számos kurzus létezik a World Wide Weben (Radford, online), mi több, számos iskola és egyetem csak online múködik (pl. Capella University az USA-ban). Az oktatás online környezetre adaptálásának egyik oka az információs társadalom elvárásaiban rejlik: a munkaerőpiacon egyre növekszik a szellemi munkások száma, növekszik az élethosszig tartó tanulás, a problémamegoldás, az IKT és a kommunikációs készségek jelentősége. A másik ok az új, felnövekvő generáció - a Net Generáció - attitüdje és elvárása, mely jelentősen különbözik a 20. század generációinak attitüdjétől, elvárásaitól (részletesen lásd Oblinger és Oblinger, 2005a). A különbözősség mértéke nagyobb, mint a korábbi generációk közötti eltérés, ezért a Net Generáció és a korábbi generációk között már nem csak egyszerúen generációs ugrásról (generation lap), hanem szakadékról (generation gap) beszélünk.

A Net Generáció tagjai alapvetően más típusú oktatást, más típusú oktatási módszereket igényelnek, mint a korábbi generációk (1. táblázat). Mások a lehetőségeik, mint a korábbi korosztályoknak, ezek determinálják életstílusukat, elvárásaikat többek között az oktatás területén is. Új lehetőségeket nyitnak mind az oktatók, mind az oktatás számára a tanulók technológiában való jártassága és az új technológia használata iránti igényük, a multitasking típusú munka, a változatosságra való igény, alapvető optimizmusuk és csoport orientációjuk (Oblinger és Oblinger, 2005a). 
Az oktatókkal szemben támasztott további kihívások egyrészről felszínes olvasási és TV nézési szokásaikból, illetve a kritikai gondolkodási képesség viszonylagos hiányából, másrészről az interneten, különböző médián talált információ hitelességének megítélési problémáiból, és a szellemi tulajdonról alkotott naiv elképzeléseikből erednek (Oblinger és Oblinger, 2005a). A Net Generáció színes, gyorsan változó, izgalmas filmeken szocializálódott. Hozzá van szokva az egy tized másodperces jelenetekhez, aminek következtében ingerküszöbük szignifikánsan magasabb, mint a szülők generációjáé (Molnár, 2008).

1. táblázat: A tanulási és tanítási paradigmákban rejlő különbségek (Brown, 2005. 126. o.)

\begin{tabular}{|l|l|}
\hline \multicolumn{1}{|c|}{ Tradicionális oktatás } & \multicolumn{1}{c|}{ A Net Generáció oktatása } \\
\hline Memorizálás & Megértés \\
\hline Felidézés & Felfedezés \\
\hline Egy alkalmas mindenkire & Személyre szabott, lehetőségekben gazdag \\
\hline Ismétlés & Transzfer és alkotás \\
\hline Tények elsajátítása & Tények és konceptuális keret \\
\hline Elszigetelt tények & Rendezett fogalmi sémák \\
\hline Tanár = mester, tudás forrása & Tanár=mentor, szakértő \\
\hline Fix szerepek & Mobil, változó szerepek \\
\hline Fix osztályterem & $\begin{array}{l}\text { Mobil, mozgatható, könnyen átalakítható } \\
\text { osztályterem }\end{array}$ \\
\hline Szummatív értékelés hangsúlya & Formatív és szummatív értékelés \\
\hline
\end{tabular}

A hardware oldaláról megközelítve, szintén egyre növekvő szakadék van az iskolák többségének IT környezete és a Net Generáció tagjai által használt technológiák között. A tanulók modernebb és fejlettebb technológiákkal találkoznak hétköznapjaik során, mint amit a legtöbb iskolában elérhetnek. Ezért fordulhat elő, hogy a tanulók tudásának egyre növekvő része az iskolán kívülről származik, melynek következményeképpen a történelem során most elöször fordul elö, hogy a gyerekek tanítják a szüleiket, az idösebb generáció tagjait (Molnár, 2008).

Az internet elterjedése és a technológia korábban sohasem látott mértékủ fejlődése az információ szerepének felértékelődését eredményezte a tudás társadalmában. Az egyre nagyobb számú információforrásokon - mint a különböző TV csatornák, folyóiratok, internetes oldalak stb. - korlátlan mennyiségü információ érhető el, melyek sem a médiában, sem az interneten nincsenek relevanciájuknak megfelelő címkékkel ellátva. Így mindenki annyi és olyan típusú és minőségü információhoz juthat, amilyenhez csak szeretne; ez a helyzet új igényeket állít az oktatással 
szemben. Felmerülnek a kérdések, hogyan kezelhetjük ezt az új helyzetet? Milyen új képességeket kell tanítani az iskolában? Meg kell-e tanítani, hogyan kell az új IKT eszközöket hatékonyan használni, mert ezek a képességek a munkaerőpiacon alapképességek közé tartoznak. Ahhoz, hogy ezt hatékonyan tegyük, új oktatási módszerek használata szükséges (például kollaboratív tanulás, probléma-alapú oktatás, projektmunka, kooperatív tanulás), melyek új típusú tanárokat igényelnek, speciális facilitátorokat, akik magas szintủ technológiai tudással és képességgel rendelkeznek, amelyeket a Net Generáció tagjai elvárnak tőlük (Roberts, 2005).

Az új jelenségek nagy kihívást támasztanak az oktatás felé, magába foglalva a középiskolai oktatást és a tanárképzést is. Nehéz feladat megfelelni a követelményeknek, mert az oktatási intézmények vezetői, tanárai, a tanárképzés pedagógusai is az előző generáció tagjai. A korábbi generációk jellemzőivel meg kell érteniük a Net Generáció elvárásait, és ezáltal megérteni, milyen tanulási környezetet kell kialakítani, ahhoz, hogy megvalósulhasson a Net Generáció hatékony oktatása (Oblinger és Oblinger, 2005b).

A tanárképzés feladata, hogy a jövő tanárai (a) elsajátítsák az oktatásban használható IKT eszközök használatát, (b) megismerjék a webes alkalmazásokat, megtanulják, hogyan alkalmazhatók az mindennapi tanítás során, illetve (c) gyakorlottá váljanak a multimédiás anyagok magas színvonalú készítésében. A multimédiás anyagok különböző digitális médiatípusok kombinációi (mint kép, hang, videó, szöveg; Molnár, 2007), amelyek elérhetők interaktívan a számítógépen. A hagyományos oktatási módszerek és anyagok, innovatív tanítási módszerek multimédiás elemekkel kombinálva az oktatásban lehetővé teszik a tanulási-tanítási folyamat integrált, több érzékszervre ható, rugalmas, interaktív alkalmazások (integrated multisensory flexible interactive application) használatát (Neo és Neo, 2001). Rugalmas, mert analóg technológiáról áttér digitális médiára; a papíralapú képek digitális fotókhoz és videókhoz társulnak, amelyek magasabb funkcionalitást biztosítanak, és új jellemzőket adnak a multimédiás típusokhoz (mint képszerkesztés, tömörítés). A Net Generáció számára, szinte az élet minden része multimédia formátumban van jelen, továbbá eredményei online megbeszéléshez vezetnek (Windham, 2005). A multimédiás anyagok több érzékszervre ható jellemzője miatt magasabb hatásfokot, produktivitást érhetünk el a megszerzendő tudás területén, mert az emberek a látottak 20\%-ára, a látottak és hallottak 40\%-ára, és egyidejűleg látottak, hallottak és készítettek 75\%-ára emlékeznek (Molnár, 2007). Továbbá a multimédia lehetővé teszi, hogy olyan tudás elemeket és képességeket mérjünk, amelyek papír-ceruza környezetben nem vagy sokkal költségesebben mérhetök (Csapó, Molnár és R. Tóth, 2009). Ez az oka annak, miért javasoljuk a technológia bevonását a tanulási aktivitásba. A multimédia nem egyenlő az online környezettel, valamint a technológia és a multimédia oktatásban való használata nem jelenti az emberek közti interakció, a faceto-face kommunikáció kizárását az oktatásból (Molnár, 2008). A multimédiás tanulási környezet innovatív eszköz lehet a hatékony tanítás-tanulás folyamat során, továb- 
bá az információ közvetítés hatékony oktatási médiumává válhat (Agnew, Kellerman és Meyer, 1996). De a technológia egyedül nem elég egy magasabb teljesítmény eléréséhez (Molnár, 2007). Egy interaktív táblát használhatunk ugyanúgy, mint egy krétás táblát, és a tanár elkövetheti ugyanazokat a módszertani hibákat az interaktív tábla elött, mint a hagyományos tábla előtt. A 21. század ideális tanórája igényli a kollaborációt (Molnár, 2008), ami könnyebben megvalósítható a technológia kínálta eszközökkel, alkalmazásokkal. A megfelelően alkalmazott, fejlett technológia fokozhatja a tanítási-tanulási folyamat hatékonyságát: a tanulók tudásának megkonstruálását, felmérését, esetleges hiányosságaik feltárását ( $R$. Tóth, Molnár és Csapó, 2008).

\section{Paradigmaváltás}

A tudás-alapú társadalom elvárja, hogy megküzdjünk azzal a hatalmas információtömeggel, amely körülvesz minket, megtaláljuk és szelektáljuk a számunkra releváns információkat. Ezeknek a tevékenységeknek a megtanítására az oktatási rendszernek jól képzett tanárokra van szüksége, akik egyben az információs és kommunikációs technológiák szakértöi is (Molnár, 2008). Hatékonyan hozzájutnak információkhoz és azt hatékonyan tovább tudják adni a diákoknak, mivel jártasak a különböző tanítási módszerekben ( $R$. Tóth és Molnár, 2009).

Thomas Kuhn (1962) szerint az érett tudományra jellemző fejlödési minta egy folytonos, a forradalom által generált átmenet egyik paradigmából a másikba. Tudományos forradalmak akkor jönnek létre, ha a régi/addig létező elméletek és módszerek már nem elegendőek az újonnan keletkező problémák megoldásához, valamint amikor a tények vagy az elméletek terén keletkező alapvető újdonságok minőségileg átalakítják és mennyiségileg gazdagítják a tudományos világot. Ezt az elméleti és metodikai változást ,paradigmaváltásnak” nevezi. A 21. század elején szemtanúi lehetünk egy ilyen paradigmaváltásnak. A 20. század generációi és a Net Generációk között jelentős mértékü különbség van. Ez új igényeket támaszt az oktatás felé, amelyek nem kivitelezhetők a hagyományos módszerekkel (Dolence és Norris, 1995), azaz kialakulóban van egy új típusú iskola iránti igény (UNESCO, 2005), ahol az elvárt ismeretek és képességek átadása során hatékonyan alkalmazzák a különböző IKT-s eszközöket (UNESCO, 2002).

Nem kétséges tehát, hogy a multimédiás alkalmazások új megvilágításba helyezik a tanulási folyamatot, és lehetőséget nyújtanak az információ, illetve a tudás új, innovatív módon történő integrálására (Molnár, 2007). A modern IKT eszközök, webes alkalmazások új lehetőséget teremtenek az oktatás színvonalának és a mindennapi tanítási gyakorlat minőségének növelésében. Az IKT-alapú tanulás és tanítás bevezetésében, fenntartásában és fejlesztésében kulcsfontosságú, vezető szerepet kell betöltenie a tanárképzéssel foglalkozó intézeteknek. Ezen fo- 
lyamat során az UNESCO (2002) a következö feltételek teljesülését nélkülözhetetlennek tartja:

- A digitális technológiákhoz és az internethez is mind a tanulók, mind a tanárok részére megfelelö hozzáférést kell biztosítani az osztályteremben, az iskolában és a tanárképző intézményekben is.

- Mind a tanulók, mind a tanárok számára biztosítani kell a magas színvonalú, értelmes és a kultúrának megfelelő digitális tartalmak elérhetőségét.

- A tanároknak rendelkezniük kell azokkal az ismeretekkel és képességekkel, amelyek lehetővé teszik az új digitális eszközök és források használatát.

A változás folyamatának első lépése, hogy a felsorolt feltételek közül információt gyüjtünk az IKT tanárképzésben betöltött jelenlegi státuszáról, illetve a tanárképzésben résztvevő hallgatók tapasztalatairól és elvárásairól. A kurzusok elvégzése során a hallgatók számára hozzáférhetővé kell tenni a szükséges hardveres és szoftveres eszközöket. Ennek teljesülése azonban nem azt jelenti, hogy a diákok el is sajátítják azt a tudást, melyet később hatékonyan kellene használniuk a tanítási gyakorlatban. Kiemelt területként kezelendő a pedagógusok tudásának, képességeinek, valamint készségeinek továbbképzésekkel történő megújítása és naprakész frissítése (UNESCO és OECD, 2001).

\section{A kutatás célja}

A kutatás célja, hogy megvizsgálja a tanári előkészítő modulban részt vevő hallgatók technológiával kapcsolatos attitüdjét, tudását és elvárásait:

- A BA hallgatók IKT-s tapasztalatait, különös tekintettel a web 1.0-es tevékenységekre és a web 2.0-es alkalmazásokra.

- Részletes képet kapni arról, hogyan használják a különböző alkalmazásokat és IKT eszközöket (mobil eszközök, személyi számítógépek, különféle szoftverek) az előkészítő tanárképző modulban résztvevők.

- Információt gyüjteni arról, milyen különböző módon (egyéni tervezés, prezentáció, kommunikáció) használják a technológiát az oktatás színvonalának növelésére.

- A jövő tanárainak milyen elvárásai vannak a tanárképzéssel szemben, melyen IKT eszközök és webes alkalmazások használatát szeretnék elsajátítani a képzés során.

A projekt hosszú távú célja, hogy növelje a tanárképzés során az IKT használat gyakoriságát, minőségét a kérdőív által szerzett információk alapján. 


\section{Módszerek}

\section{Minta}

A mintát (N=203) a Szegedi Tudományegyetem neveléstudomány iránt érdeklődő, első-, másod- és harmadéves, többségében tanári előkészítő modulban részt vevő hallgatói alkották. A minta tagjai az egyetem négy karáról kerültek ki: a Bölcsészettudományi (BTK), a Természettudományi és Informatikai (TTIK), a Juhász Gyula Pedagógusképző (JGYPK) és a Zeneművészeti Karról (ZMK). A hallgatók 86,4\%-a egyszakos hallgató. A levelező tagozatos hallgatók aránya $37,8 \%$; a minta 32,2\%-a férfi. A kérdőívet kitöltők 66,2\%-a gimnáziumból érkezett az egyetemre, és az egyetem elvégzése után a hallgatók 73,2\%-a szeretne ténylegesen tanítani.

\section{A méröeszköz és az adatfelvétel}

Az egyetemi hallgatók IKT használati szokásait, tapasztalatait és preferenciáit kérdőíves vizsgálattal végzetük, papír-ceruza formátumban. Az elkészített 80 itemes, többségében négyfokozatú, Likert-típusú állításokat tartalmazó kérdőív a hallgatók egyéni háttérinformációin túl (tagozat, nem, középiskola típusa, számítógépes, illetve internet használatában való jártasság, jövőbeni tanítási szándék) az alábbi területekre koncentrált:

1. a web 1.0 és web 2.0-es alkalmazásokban való jártasság;

2. IKT ismeretek feltérképezése;

3. a hallgatók egyéni tapasztalatainak vizsgálata, azaz a megkérdezettek tanárai milyen gyakran használtak régi (írásvetítö, diavetítö) és modern IKT eszközöket (interaktív tábla, szavazóegység) a tanítási órán;

4. a tanárképzéssel kapcsolatos elvárások, hallgatói preferenciák megismerése, vagyis milyen IKT eszközök és webes alkalmazások használatát tartják fontosnak és szeretnék elsajátítani a képzés során.

Az adatfelvétel 2008 decemberében és 2009 januárjában zajlott, amikor az SZTE Neveléstudományi Intézet által meghirdetett kurzusok írásbeli vizsgáját követően a hallgatók kitöltötték az IKT használati kérdöívet.

\section{Eredmények}

\section{A kérdöív megbizhatósága}

A kérdőív megbízhatóságának vizsgálatára a Cronbach- $\alpha$ mutatót alkalmaztuk. A reliabilitás-mutatót a kérdőív három fö komponensére (az IKT-hoz kapcsolódó ismeretek, az IKT tapasztalat a tanítási órán és a tanárképzéssel kapcsolatos elvárások) kiszámítva 0,83,0,81, és 0,89-es indexeket kaptunk, melyek alapján megállapít- 
ható, hogy a kérdőív megbízhatóan mér. A kapott eredményeket a 2. táblázat foglalja össze.

2. táblázat: A kérdőív reliabilitásmutatói (Cronbach- $\alpha)$

\begin{tabular}{|l|c|c|}
\hline \multicolumn{1}{|c|}{ Komponens } & Cronbach- $\alpha$ & Itemszám \\
\hline IKT ismeretek & 0,83 & 18 \\
\hline IKT tapasztalat & 0,81 & 18 \\
\hline Elvárások a tanárképzéssel szemben & 0,89 & 34 \\
\hline
\end{tabular}

A webes alkalmazások használatában való jártasság és a hallgatók IKT ismereteinek feltérképezése

A minta résztvevői gyakorlott számítógép és internethasználók - a hallgatók 97,0\%-a már több mint 3 éve használ számítógépet, és 95,5\%-a legalább hetente 3-4 alkalommal internetezik.

A primer adatokból faktoranalízis segítségével aggregált mutatókat képeztünk, melyek a kérdőívben megadott IKT tevékenységek együttjárásának vizsgálatához szükségesek. A változó rendszer faktoranalízisre való alkalmasságát a Kaiser-MeyerOlkin-indexet (KMO) kiszámításával igazoltuk, melynek értéke 0,77. A modell által megmagyarázott variancia $61,58 \%$. Az elemzés végeredményeként hat, egymástól szignifikánsan különböző faktor keletkezett (3. táblázat):

1. Alap IKT tudás (e-mailek írása, olvasása és szövegszerkesztés). Ezek a tevékenységek a hallgatók mindennapi életének szerves részét képezik, így többségük segítség nélkül el tudja végezni.

2. Haladó IKT tudás (prezentációkészítés, diagramkészítés és táblázatkezelés). Ezek a tevékenységek már nélkülözhetők a mindennapi gyakorlatban, csak bizonyos kurzusok elvégzéséhez szükségesek. Így ezekben már nem olyan jártasak $(\mathrm{t}=11,9, \mathrm{p}<0,05)$ mint az alap IKT tevékenységekben.

3. Magas szintü IKT tudás (multimédiás tartalmak - film, zene, kép, digitális tananyag - készítése és weboldalkészítés). Ezek a tevékenységek a jövő tanárainak alapvető IKT tudáselemei, melyek nélkülözhetetlenek a multimédia projektek elkészítéséhez.

4. Web 1.0-es tevékenységek (információkeresés az interneten, fájl letöltés). Az olvasható (read-only) webhez kapcsolódó tevékenységek elvégzésében a hallgatók gyakorlottnak bizonyultak, azonban jártasságuk jelentősen eltér $(\mathrm{x} 1=1,04, \mathrm{x} 2=2,15, \mathrm{t}=19,8, \mathrm{p}<0,05)$ a web 2.0-es alkalmazásokétól.

5. Web 2.0-es alkalmazások használata (ritkábban használt alkalmazások). Az olvasható-írható (read-write) web tevékenységek, mint a blogolás $(\mathrm{x}=2,55, \mathrm{SD}=1,37)$, wikik szerkesztése $(\mathrm{x}=2,67, \mathrm{SD}=1,32)$ vagy a linkmegosztó szolgáltatások használata $(x=2,65, \mathrm{SD}=1,32 ; 1=$ egyedül is el tu- 
dom végezni; .. ; 4=sohasem próbáltam) még nem vált a hallgatók hétköznapjainak integrált részévé. Egyetlen kivételt képez a közösségi oldalak használata (pl.: IWIW, Facebook), mely jobban kapcsolódik a hallgatók mindennapi tevékenységéhez.

6. Web 2.0-es alkalmazások (gyakrabban használt). Ide tartoznak a közösségi oldalak, 1. fent.

3. táblázat: Faktoranalízis eredménye, az IKT ismeretek különböző komponensei

\begin{tabular}{|c|c|c|c|c|c|c|}
\hline & \multicolumn{6}{|c|}{ Faktorok } \\
\hline & 1 & 2 & 3 & 4 & 5 & 6 \\
\hline \multicolumn{7}{|l|}{ Alap IKT ismeretek } \\
\hline E-mail írás, olvasás & 0,17 & $-0,12$ & 0,01 & $-0,13$ & 0,78 & $-0,08$ \\
\hline Szövegszerkesztés & $-0,12$ & 0,33 & 0,10 & 0,27 & 0,61 & 0,36 \\
\hline \multicolumn{7}{|l|}{ Haladó IKT ismeretek } \\
\hline Prezentációkészítés & 0,14 & 0,05 & 0,74 & 0,08 & $-0,24$ & 0,15 \\
\hline Diagramkészítés & 0,11 & 0,18 & 0,78 & $-0,04$ & 0,17 & $-0,13$ \\
\hline Táblázatkezelés & 0,04 & 0,35 & 0,55 & 0,16 & 0,29 & 0,00 \\
\hline \multicolumn{7}{|l|}{ Magas szintü IKT tudás } \\
\hline Film- és zeneszerkesztés & 0,43 & 0,64 & 0,18 & $-0,01$ & $-0,11$ & $-0,17$ \\
\hline Képszerkesztés & 0,03 & 0,72 & 0,02 & 0,27 & 0,17 & 0,02 \\
\hline Digitális tananyagszerkesztés & 0,28 & 0,63 & 0,23 & $-0,06$ & $-0,16$ & 0,10 \\
\hline Weboldalak készítése & 0,35 & 0,57 & 0,21 & $-0,23$ & 0,06 & 0,11 \\
\hline \multicolumn{7}{|l|}{ Web 1.0-s tevékenységek } \\
\hline Információkeresés az interneten & $-0,05$ & $-0,11$ & 0,10 & 0,73 & 0,06 & 0,24 \\
\hline Fájlok letöltése & 0,25 & 0,23 & 0,03 & 0,72 & $-0,10$ & $-0,24$ \\
\hline \multicolumn{7}{|l|}{ Web 2.0 alkalmazások } \\
\hline Fájlfeltöltés & 0,71 & 0,09 & $-0,07$ & 0,21 & $-0,07$ & 0,11 \\
\hline Online játékok & 0,65 & 0,00 & 0,25 & 0,12 & 0,19 & 0,07 \\
\hline Blogolás & 0,60 & 0,21 & 0,26 & $-0,24$ & $-0,06$ & 0,32 \\
\hline Wikik szerkesztése & 0,75 & 0,28 & $-0,03$ & $-0,04$ & 0,03 & $-0,02$ \\
\hline Online térképalkalmazások & 0,46 & 0,11 & 0,31 & 0,12 & 0,31 & $-0,37$ \\
\hline Linkmegosztó szolgáltatások & 0,55 & 0,31 & 0,16 & $-0,04$ & 0,07 & 0,10 \\
\hline \multicolumn{7}{|l|}{ Web 2.0 alkalmazások II. } \\
\hline Közösségi portálok & 0,30 & 0,06 & 0,01 & 0,07 & 0,03 & 0,76 \\
\hline
\end{tabular}

Megjegyzés: főkomponens-analízis Varimax rotációval 
A 3. táblázatban kiemelt változókat aggregálva, külön változóként kezelhetjük, melyeket a részmintákra irányuló elemzésekhez használtunk fel. A tanári előkészítő modulban résztvevő első $(\mathrm{N}=25)$ és harmadik $(\mathrm{N}=128)$ évfolyamos hallgatók válaszai arra engednek következtetni, hogy a bachelor képzésben a hallgatók nem jutnak el magasabb felhasználói szintre az újabb eszközök használatában, azaz nem érzik magabiztosabbnak magukat az IKT tevékenységek végrehajtásakor. A pilot mérés eredményei azt mutatják, hogy az IKT tevékenységekben való jártasság az első és a harmadik évfolyamosok között nem jelentős, azonban például a weboldalkészítésben $\left(\mathrm{x}_{1}=2,2, \mathrm{x}_{3}=3,0, \mathrm{t}=3,9, \mathrm{p}<0,05\right)$, a wikik szerkesztésében $\left(\mathrm{x}_{1}=2,2\right.$, $\left.\mathrm{x}_{3}=2,9, \mathrm{t}=2,7, \mathrm{p}<0,05\right)$ az első évfolyamosok szignifikánsan magabiztosabbak. Egyéb háttérváltozók - mint tagozat (nappali, levelező), középiskola típusa (gimnázium, szakközépiskola), jövőbeli tanítási szándék - mentén képzett részminták IKT tevékenységekben való jártassága között sincs szignifikáns különbség. Nemek szerinti bontásban csak a ritkábban alkalmazott web 2.0-es alkalmazások esetén figyelhető meg jelentős eltérés $\left(\mathrm{x}_{\mathrm{fiu}}=1,91, \mathrm{SD}=0,84 ; \mathrm{x}_{\text {lány }}=2,26, \mathrm{SD}=0,79, \mathrm{t}=2,8\right.$; $\mathrm{p}<0,05)$.

\section{Hallgatók egyéni tapasztalatainak vizsgálata - IKT eszközök használata a tanitási órán}

A hallgatók tapasztalatai alapján (1. ábra) a középiskolai és az egyetemi tanárok leggyakrabban (havonta többször) számítógépet $(55,5 \%)$, projektort $(54,3 \%)$ és írásvetítőt $(50,8 \%)$ használnak az órákon.

$\mathrm{Az}$ újabb eszközök - interaktív tábla (14,2\%), digitális fényképezőgép/kamera $(4,6 \%)$, szavazóegység $(3,1 \%)$, a tablet PC $(3,6 \%)$, UMPC $(2,6 \%)$ - használata szignifikánsan $\left(\mathrm{x}_{1}=3,35, \mathrm{x}_{2}=1,46, \mathrm{t}=26,6, \mathrm{p}<0,05\right)$ ritkábbnak bizonyult, holott ezen eszközök a korábbiakhoz képest újabb lehetőségeket teremtenek a tanóra változatosabbá, mozgalmasabbá tételére.

A hallgatók többsége a Net Generáció tagja, ezért szívesen tanulnak számítógép segítségével. Ezzel szemben tanáraik, ezt figyelmen kívül hagyva, az oktatás folyamán mellőzik az oktatási szoftverek, illetve webes alkalmazások használatát (1. 4. táblázat). A megkérdezett hallgatók jelentős része nem találkozott még a wikik $(78,6 \%)$, blogok $(91,4 \%)$, digitális napló $(87,2 \%)$, a Sulinet Digitális Tudásbázis (72,3\%) (részletesebben lásd Dancsó, 2007), CD/DVD-n, vagy interneten elérhetö oktató szoftverek $(52,8 \%)$ iskolai alkalmazásával. 
पszámítógép

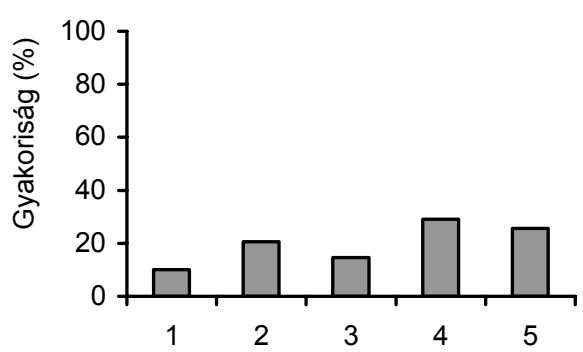

aprojektor

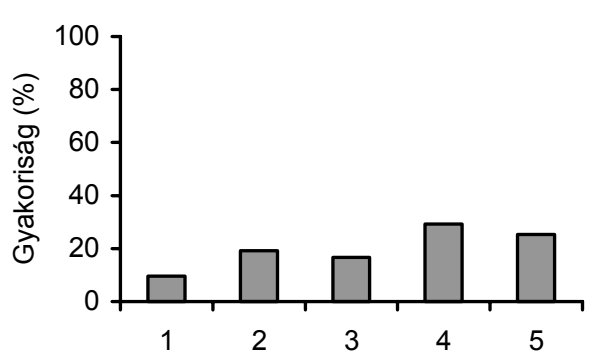

口írásvetítő

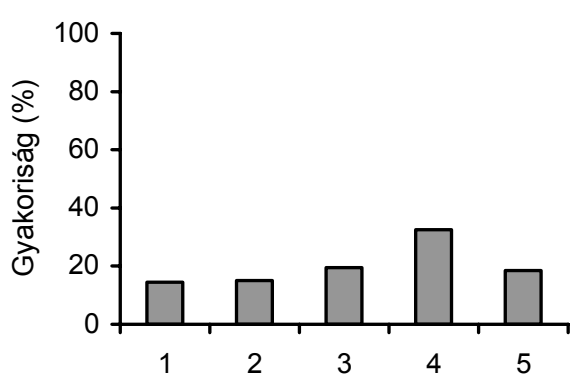

$\square$ digitális kamera

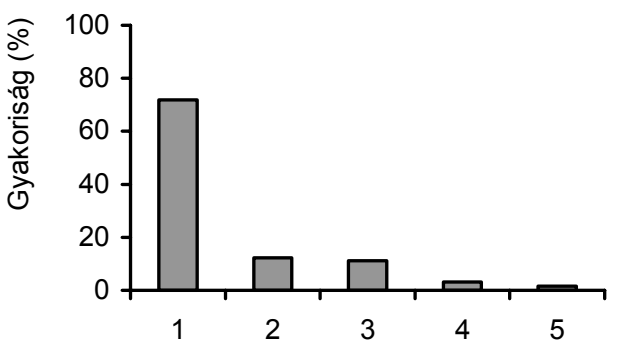

口szavazóegység

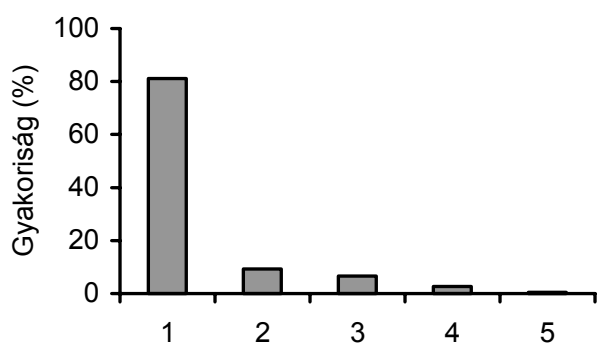

$\square$ Tablet PC $\square$ UM PC

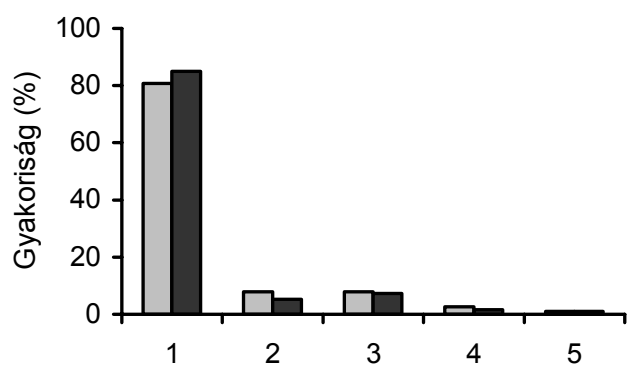

1. ábra: Az IKT eszközök használatának gyakorisági eloszlása

(Skála: $1=$ soha; 2 =évente, $3=$ =élévente, 4=havonta néhányszor; $5=$ szinte minden órán) 
4. táblázat. A webes alkalmazások és szoftverek osztálytermi használatának gyakorisága ( $1=$ soha, $2=$ évente néhányszor, $3=$ =élévente néhányszor, $4=$ havonta néhányszor, $5=$ szinte minden órán)

\begin{tabular}{|l|c|c|}
\hline \multicolumn{1}{|c|}{ Item } & Átlag & Szórás \\
\hline Oktatási szoftverek & 1,95 & 1,20 \\
\hline Sulinet Digitális Tudásbázis & 1,44 & 0,83 \\
\hline Blogok & 1,16 & 0,62 \\
\hline Wikik & 1,41 & 0,93 \\
\hline Digitális napló & 1,20 & 0,64 \\
\hline Tananyagmegosztó portálok & 1,72 & 1,14 \\
\hline
\end{tabular}

A tanárképzéssel kapcsolatos elvárások - egyéni tapasztalatok hatása az elvárások alakulására

A kérdőívben hangsúlyosan jelennek meg a hallgatók tanárképzéssel szemben állított elvárásai. Feltártuk azokat az IKT eszközökhöz kapcsolódó tevékenységeket, amelyek elsajátítását a jövő tanárai fontosnak vagy épp indokolatlannak tartanak. A dokumentációs tevékenységek (szövegszerkesztés, diagramkészítés, táblázatkezelés), a tanítási órán (prezentációkészítés), illetve az arra felkészülés (képszerkesztés, film- és zenevágás, digitális tananyagszerkesztés, weboldalkészítés) során szükséges tevékenységek közül a hallgatók által legkevésbé fontosnak tartott a képszerkesztés $(73,8 \%$ tartja fontosnak) és filmvágás $(73,3 \%)$. A legtöbbek által lényegesnek tartott tevékenység a prezentációkészítés $(90,4 \%)$ és a digitális tananyagszerkesztés $(88,2 \%)$. Ennek oka feltehetően az, hogy az egyetemi képzés során az előadók jelentős része digitális anyagok (power point fóliák) kivetítésével teszi követhetőbbé az előadást. Igy a hallgatók fontosnak tartják a tevékenység elsajátítását, de azt nem tudják, hogy a képszerkesztés és filmkészítés sokszor része a digitális anyagok elkészítésének.

A vizsgálatot a webes alkalmazások használatára is kiterjesztettük. Az 5. táblázatban web 1.0-es és web 2.0-es tevékenységekre bontva adjuk meg az eredményeket. A százalékos eredmények azon hallgatók arányát tükrözik, akik nem tartják fontosnak a felsorolt oktatásban alkalmazható tevékenységek elsajátítását.

Kiemelkedik az online számítógépes játékok használatának elutasítása - a hallgatók 75,7\%-a szerint nem fontos az oktatás számára -, noha például a szem-kézmozgás koordináció, az együttmüködési készség fejlesztésére is alkalmas. Ezeknek a játékoknak (educational serious game) az elkészítése, és a játék során összegyüjtött adatok kiértékelése a pedagógusok és informatikusok hatékony együttmüködése révén valósítható meg. 
5. táblázat: $A$ hallgatók tanárképzéssel szemben támasztott elvárásai

\begin{tabular}{|c|c|c|c|c|}
\hline \multirow{2}{*}{ Kategória } & \multirow{2}{*}{ Item } & \multicolumn{2}{|c|}{ Nem fontos elsajátitani (\%) } & \multirow{2}{*}{$\begin{array}{c}\ddot{O ̈ s s z e s e n} \\
(\%)\end{array}$} \\
\hline & & Ismeri & Nem ismeri & \\
\hline \multirow{3}{*}{ Web 1.0} & E-mailek írása, olvasása & 52,04 & 0,51 & 52,55 \\
\hline & Információkeresés & 25,91 & 0,52 & 26,43 \\
\hline & Fájlletöltés & 38,14 & 1,03 & 39,17 \\
\hline \multirow{6}{*}{ Web 2.0} & Fájlfeltöltés & 39,27 & 5,76 & 45,03 \\
\hline & Online játékok & 57,14 & 18,52 & 75,66 \\
\hline & Blogolás & 37,37 & 18,95 & 56,32 \\
\hline & Wikik szerkesztése & 24,47 & 7,45 & 31,92 \\
\hline & Online térképalkal. & 26,80 & 6,19 & 32,99 \\
\hline & Linkmegosztó szolg. & 22,88 & 14,58 & 36,46 \\
\hline
\end{tabular}

Ezentúl magas azon hallgatók aránya, akik az e-mail írást, olvasást, a fájl le- és feltöltés elsajátítását nem tartják fontosnak, melynek oka lehet, hogy a hallgatók 99,5\%-a önállóan el tud olvasni, illetve küldeni egy elektronikus levelet, 93,6\%-uk magabiztos a fájlletöltésben és 59,4\%-uk a fájlfeltöltésben is. Az információkeresés elsajátítását azonban a diákok $73,6 \%$ fontosnak tartja, annak ellenére, hogy ezt magabiztosan el tudják végezni, és a hozzá kapcsolódó fájlmúveleteket jól ismerik. Feltehetően azt várják a tanárképzéstől, hogy mindennapi tanítás során alkalmazható, a tanórára történő felkészüléskor segítséget nyújtó tananyagmegosztó, fájlmegosztó portálokat megismerjék, ahonnan a témájukhoz kapcsolódó, már kipróbált tananyagokat (például fizikai, kémiai kísérletek bemutatóit vagy a tananyagot illusztráló, kiegészítő képeket) letölthetnek.

A vizsgálatot kiegészítettük a tanórán alkalmazható modern és régi oktatási eszközök használatának elsajátítási szándék felmérésével. A hallgatók válaszaikat négyfokozatú skálán $(1=$ nem, mert nem szükséges a tanórán, $2=$ nem, mert már jól ismerem, 3=szívesen hallanék róla, 4=nagyon szeretném megtanulni) adták meg. A kérdőívben alkalmazott elméleti modell szerint az újabb IKT eszközök kezelését szeretnék, a háztartásokban megtalálható és a régi kivetítő eszközök (diavetítő és írásvetítő) használatát nem tartják indokoltnak a hallgatók elsajátítani. Ezt a modellt a kérdőív kitöltésével kapott adatokon nyugvó, faktoranalízissel nyert struktúrával egybevetve megállapíthatjuk, hogy az elméleti modell csak részben teljesült. A faktoranalízis elvégzése jogos volt, mert a KMO-index 0,83, a modell által megmagyarázott összvariancia $74,76 \%$. A faktoranalízis három faktort eredményezett: (1) a legtöbb háztartásban fellelhetö, mindennapokban használt (számítógép, TV, CD/DVD lejátszó, magnó, illetve digitális fényképezőgép/kamera), (2) a régi kivetítő (írásvetítő, diavetítö) és (3) a modern oktatási eszközök (projektor, szavazóegység, 
interaktív tábla, Tablet és UM PC) faktorát. A faktorok segítségével aggregált változókat képeztünk, mely alapján megállapítható, hogy a modern oktatási eszközök elsajátítási hajlandósága szignifikánsan magasabb, mint az első ( $\mathrm{x}_{\text {háztartás }}=2,36, \mathrm{sd}=0,70$; $\left.\mathrm{x}_{\text {modern }}=3,09, \mathrm{sd}=0,71 ; \mathrm{t}=12,65, \mathrm{p}<0,05\right)$, illetve a második $\left(\mathrm{x}_{\text {régi }}=2,36, \mathrm{sd}=0,89\right.$; $\left.\mathrm{x}_{\text {modern }}=3,09, \mathrm{sd}=0,71 ; \mathrm{t}=11,55, \mathrm{p}<0,05\right)$ faktor elemeié. A faktorok között leginkább differenciáló tényező az eszközök ismerete és a tanításban betöltött szerepe. A számítógép (44,2\% jól ismeri), a TV (62,8\%), a CD/DVD lejátszó $(68,2 \%)$, a magnó $(66,7 \%)$ és a digitális fényképezőgép, illetve kamera $(47,2 \%)$ használatát a tanulók jelentős része jól ismeri, ezért kevesebben szeretnék ezen eszközök használatát elsajátítani, mint a modern oktatási eszközökét (projektor - 20,7\% jól ismeri; szavazóegység $-4,6 \%$; interaktív tábla $-6,6 \%$; tablet PC $-3,1 \%$ és UMPC $-3,1 \%$ ). A régi típusú kivetítő eszközök - írásvetítő (42,1\% jól ismeri), diavetítő $(43,7 \%)$ használatát a tanulók több mint 40\%-a jól ismeri, ugyanennyien viszont szeretnének még tanulni róla. Melyből az a következtetés vonható le, hogy az újabb IKT eszközök még mindig nem szorították ki a minőségileg kevésbé hatékony, régi típusú oktatási eszközök szerepét.

Az egyéni tapasztalat hatását példázza, hogy azon hallgatók jelentős része nem tartja fontosnak az oktatási blogok $(58,3 \%)$, wikik $(36,6 \%)$ vagy a digitális napló $(16,9 \%)$ használatának elsajátítását, akik korábban valamilyen óra keretében nem találkoztak ezekkel az alkalmazásokkal. Ezért a tanárképzés feladata, hogy megtanítsa az innovatív eszközök használatát, és példát mutasson az eszközök alkalmazási területeire a mindennapi tanítási gyakorlatban.

Molnár (2008) által végzett pilot kérdőíves vizsgálat eredményei is alátámasztják a tanárképzéssel kapcsolatos elvárásokat. Ebben a vizsgálatban 4. és 5. évfolyamos $(\mathrm{N}=40)$ tanár szakos hallgatókat vizsgált több IKT kurzus keretében, ahol megtanulhatták a hallgatók a különböző oktatási szoftverek és multimédiás eszközök használatát. A félév elején és végén készült összehasonlító felmérés eredményei alapján megállapítható, hogy a számítógép mellett az interaktív tábla és a szavazóegység használatában látták a hallgatók a legnagyobb oktatási lehetőségeket. A tanulók 60\%-a tablet PC-t és UMPC-t legalább heti egy alkalommal használna a mindennapi tanítási gyakorlatban, és csak 10\%-ra tehető azon hallgatók aránya, akik soha nem használnák ez utóbbi két eszközt.

\section{Összegzés}

Az eredményeket összegezve megállapíthatjuk, hogy a vizsgálatban résztvevők gyakorlottak a World Wide Web és a számítógép használatában. A webes alkalmazások használatában való jártasság és a hallgatók IKT ismereteinek feltérképezése során az IKT ismeretek hat komponensét tártuk fel faktoranalízis segítségével. Ezek alapján a hallgatók az alap IKT képességeket igénylő szoftverek alkalmazásában jártasnak bizonyultak. Azonban a haladó, illetve magasabb szintü IKT isme- 
reteket feltételező és a web 2.0-es alkalmazások használata fejlesztésre szorul a tanárképzés során. Megvizsgálva a különböző évfolyamba járó hallgatók IKT ismereteit, az eredmények arra engednek következtetni, hogy az első és a harmadik évfolyamos hallgatók IKT ismeretei, jártassága között nincs jelentős elétérés.

Az IKT eszközök tanítási órái használatát a hallgatók tapasztalataira alapozva, a középiskolai és egyetemi tanáraik IKT használati szokásaik alapján tártuk fel. A hallgatók egyéni tapasztalatai alapján meghatározható, hogy a számítógép, a projektor és az írásvetítő a leggyakrabban használt tanórai eszköz. Ugyanakkor a digitális kamera, a szavazóegység, a tablet PC és UMPC használata a legkevésbé elterjedt, valamint a hallgatók többsége nem vagy csak nagyon ritkán találkozik a web 2.0-es alkalmazásokkal, illetve CD/DVD formájában vagy interneten elérhető oktatási szoftverekkel a tanórán.

A BA képzésben részt vevő hallgatók tanárképzéssel kapcsolatos elvárásaiban jelentős szerepet tölt be a prezentációkészítés és a digitális tananyagok készítése, ugyanakkor ezen tevékenységekhez füződő alkalmazások, mint képszerkesztő, filmvágó szoftverek használata számukra a legkevésbé fontos tevékenységek közé tartozik. A leginkább elutasított alkalmazás a számítógépes játék, továbbá számos web 2.0-es alkalmazás elsajátítását sem tartják indokoltnak. Az IKT eszközök közül legkevésbé a mindennapi életükben jelenlévő eszközökről szeretnének ismereteket szerezni, míg a régi típusú (írásvetítő, diavetítö) eszközök használatát a hallgatók 40\%-a szeretné elsajátítani. A modern IKT eszköz (szavazóegység, interaktív tábla, tablet PC, UMPC, projektor) hatékony használatát szeretnék a legtöbben megtanulni.

Az eredmények alátámasztják, hogy az egyéni tapasztalatok jelentős hatást gyakorolnak a hallgatók elvárásaira, azaz mely eszközök, szoftverek megismerését tartják fontosnak a tanárképzés során. Azok a hallgatók, akik tanárai nem használták a modern oktatási webes alkalmazásokat és szoftvereket oktatási célra (pl.: blogok, wikik, digitális napló), azok nem is szeretnének ezekről az eszközökről tanulni. Ugyanakkor a Molnár (2008) pilot kutatása alapján megállapítható, hogy ha a hallgatók a tanárképzés során elsajátítják a modern IKT eszközök, illetve ezekhez tartozó szoftverek használatát, akkor szeretnék alkalmazni azokat a mindennapi tanítási gyakorlatban is.

Összességében az általános-, középiskolás és felsőoktatásban dolgozó tanárok, illetve a hallgatók tanórai tapasztalati jelentős mértékü hatást gyakorolnak a jövő tanárainak attitüdjére, terveire, így a jövőbeni tanári gyakorlatára is. Ezért a tanárképzés feladata, hogy megtanítsa a tanároknak ezen eszközök, alkalmazások hatékony használatát egy hatékonyabb tanítási-tanulási folyamat megvalósításához. 


\section{Irodalom}

Agnew, P. W., Kellerman, A. S., Meyer, J. (1996): Multimedia in the Classroom. Allyn and Bacon, Boston.

Brown, M. (2005): Learning Spaces. In: Oblinger, D. G. and Oblinger, J. L. (szerk.): Educating the Net Generation. EDUCAUSE. 12.1.-12.22.

Csapó Benő, Molnár Gyöngyvér, R. Tóth Krisztina (2009): Comparing paper-and-pencil and online assessment of reasoning skills: A pilot study for introducing TAO in largescale assessment in Hungary. In: Friedrich Scheuermann, Julius Björnsson (szerk.): The Transition to Computer-Based Assessment: New Approaches to Skills Assessment and Implications for Large-scale Testing. Luxemburg: Office for Official Publications of the European Communities, 2009, 113-118.

Dancsó Tünde (2007): A digitális pedagógia fejlesztése a Sulinet Digitális Tudásbázis alkalmazásával. Új Pedagógiai Szemle, 3-4. sz. 126-133.

Dolence, M., Norris, D. (1995): Transforming higher education: A Vision for learning in the 21st century. Society for College and University Planning, Ann Arbor, Mich.

Hinrichs, R. (2000): A Vision for Life Long Learning - Year 2020. Introduction by Bill Gates. Learning Science and Technology Microsoft Research. Microsoft.

Kuhn, T. (1962): The Structure of Scientific Revolutions. University of Chicago Press, Chicago.

Molnár Gyöngyvér (2007): New ICT Tools in Education - Classroom of the Future Project. In: Dragan Solesa (szerk.): The fourth international conference on informatics, educational technology and new media in education. A. D. Novi Sad. 332-339.

Molnár Gyöngyvér (2008): The use of innovative tools in teacher education: a case study. In: Dragan Solesa (szerk.): The fifth international conference on informatics, educational technology and new media in education. A. D. Novi Sad. 44-49.

Neo, M., Neo, K. T. K. (2001): Innovative teaching: Using multimedia in a problem-based learning environment. Educational Technology \& Society 4 (4).

Oblinger, D. G., Oblinger, J. L. (2005a): Is It Age or IT: First Steps Toward Understanding the Net Generation. In: Oblinger, D. G. and Oblinger, J. L. (szerk.): Educating the Net Generation. EDUCAUSE. 2.1-2.20.

Oblinger, D. G., Oblinger, J. L. (2005b, szerk.): Educating the Net Generation. EDUCAUSE.

R. Tóth Krisztina, Molnár Gyöngyvér (2009): ICT skills and preferencies of students in bachelor teacher education. Paper presented at 6th International Conference on Informatics, Educational Technology and New Media in Education. Sombor, Szerbia, March 28-29, 31.

R. Tóth Krisztina, Molnár Gyöngyvér, Csapó Benő (2008): A számitógépes tesztelés lehetöségei. VI. Pedagógiai Értékelési Konferencia, Szeged, 2008. április 11-12. 84.

Roberts, G. R. (2005): Technology and Learning Expectations of the Net Generation. In: Oblinger, D. G. and Oblinger, J. L. (szerk.): Educating the Net Generation. EDUCAUSE. 3.1-3.7. 
UNESCO (2002): Information and communication technologies in teacher education. UNESCO, Paris. http://unesdoc.unesco.org/images/0012/001295/129533e.pdf

UNESCO (2005): Information and communication technologies in schools. A handbook for teachers or how ICT can create new, open learning environments. UNESCO, France.

UNESCO, OECD (2001): Teachers for tomorrow's schools. Analyses of the world education indicators. UNESCO, Paris.

Windham, C. (2005): The Student's Perspective. In: Oblinger, D. G. and Oblinger, J. L. (szerk.): Educating the Net Generation. EDUCAUSE. 5.1-5.16. 